\title{
Effects of Teacher Training on Secondary Teachers' Mathematical Content Knowledge in Dhaka, Bangladesh
}

\author{
Sheikh Asadullah
}

\author{
School of Education, University of New South Wales (UNSW), Australia
}

\begin{abstract}
In Bangladesh, there are improvements in secondary education by quantitative indicators but the satisfactory picture is remained far from the quality. The gross deficiency in teaching includes one of the main reasons for poor quality of secondary education. There are higher failure rates in Mathematics subject in Secondary School Certificate examination in the last consecutive years. An extensive review of research has shown that teachers account to a large extent for student learning and achievement gains. For secondary teacher education in Bangladesh, there is a one-year long training program named as Bachelor of Education (B.Ed.). Therefore, the study sought to find out the effectiveness of B.Ed. training program on mathematics teachers' content knowledge as a mean of improving secondary school mathematics in Bangladesh. The study was conducted among 38 mathematics teachers (trained and untrained) selected from 16 secondary schools of Dhaka city using survey method. Teacher's content knowledge was measured through an assessment test and classroom teaching observation. The study found that though the B.Ed. trained mathematics teachers $(96.3 \%)$ possess better content knowledge than their counterpart $(91.7 \%)$ but no relationship between teachers' personal characteristics and their content knowledge in mathematics. This is the first study to investigate the effectiveness of secondary teacher education program within Bangladesh. It contributes important insights about secondary teacher education that can be used to inform the professional development of the secondary school mathematics teachers in Bangladesh.
\end{abstract}

Keywords: Content knowledge, Secondary school mathematics teachers of Bangladesh, Bachelor of Education, Teachers training college

\section{INTRODUCTION}

Bangladesh has seen education as critical to poverty reduction, economic progress and prosperity (Andeleeb, 2007; Ministry of Education $[\mathrm{MoE}], 2012$ ) and have made "international commitments to ensure the achievement of 'education for all' goals and targets for every citizen by the year 2015" (Rahman, Hamzah, Meerah \& Rahman, 2010, p. 115). Thus, various government and nongovernment initiatives have resulted in significant progress with regard to access to both primary and secondary education such as more schools and teachers, curriculum revision and increased enrolment rates especially for girls in secondary education (Rahman et al., 2010). Also, for enhancing the quality of primary and secondary education the government of Bangladesh has been considering teacher education as a major factor. In the secondary education of Bangladesh a one-year Bachelor of Education (B. Ed) teacher education program is being provided by the Teacher Training Colleges (TTCs) to build teacher capacity in the form of new knowledge, skills and attitudes and in the application of these in teaching practice (B.Ed. Curriculum, 2006-2007). Despite the significant progress in access, equity and public examination success; weakness has been identified in the quality of secondary education particularly in the students' mathematics achievement (Ahmed, Nath, Hossain \& Kalam, 2006; Nath et al., 2007). For example, poor student performance in year eight (Junior Secondary year ten (Secondary Certificate) and School Certificate) public examinations has been attributed to consistently high failure rates in English and Mathematics. An extensive review of 
research (see Hattie, 2003, 2009) has shown that teachers account to a large extent for student learning and achievement gains. Several studies (see Ahmed et al., 2006; Nath et al., 2007) have attributed poor student performance and low-quality education to poor instructional practices of teachers as one of the main reason in Bangladesh. Again, there is consensus in teaching and teacher education literature (Bransford, Darling-Hammond \& LePage, 2005; Grossman \& McDonald, 2008; Hiebert, Morris, Berk \& Jansen, 2007; Munby, Russell \& Martin, 2001) that content-specific knowledge, general pedagogical knowledge and skills are important determinants of instructional quality that affect students' learning gains. In mathematics domain, content knowledge establishes an essential foundation for teacher's pedagogical knowledge and skills for teaching mathematics (Ernest, 1989). Rowan, Chaing \& Miller (1997) put the rationale that a deep understanding of the subject being taught facilitates teachers in planning and in the academic interaction in teaching. Consistent with the rationale, studies (Fennema \& Franke 1992: Swafford, Jones \& Thornton, 1997) also revealed that mathematical content knowledge can lead to higher-quality instruction. However, researchers had acknowledged that the profession specific content knowledge is acquired through formal training, university-level training and can be cultivated through systematic reflection on classroom experience (Ball, Lubienski \& Mewborn, 2001; Baumart et al., 2010; Berliner, 1994; Grossman, 2008).

Therefore, studies are needed to find out the effect of the B. Ed teacher training program on secondary teachers content knowledge. No empirical studies conducted earlier the present study in the secondary education sector of Bangladesh to evaluate the effectiveness of teacher education programs. The studies (ADB 2002, 2004; MoE 2004) investigated the factors affecting the quality of secondary education and the prevailing problems of teacher education system in Bangladesh. The studies were not conducted on teachers' training objectives or teacher competencies developed through training. Therefore, this study was the first study conducted on Bangladesh secondary education in order to investigate the effectiveness of a teacher education program. However, to examine the quality of all these teacher training programs was not the scope of this study. This study rather attempted to measure the effectiveness of the B.Ed. program on mathematics with regard to developing profession specific mathematical content knowledge of secondary school mathematics teachers in Bangladesh.

\section{SECONDARY EDUCATION IN BANGLADESH}

Secondary education in Bangladesh caters adolescents aged 11-17 years and includes two stages, the secondary stage (or grades 6-10) and higher secondary stage (or grades 11-12). The secondary stage is further divided into the junior secondary (or grades 6-8) and senior secondary (or grades 910 ). At the end of the junior secondary stage (or grade 8 ), the learning achievement of a student is assessed at a public examination, known as the Junior School Certificate (JSC) in the general stream, and the Junior Dakhil Certificate (JDC) in madrasah stream. A student who passes the JSC or JDC may proceed to the senior secondary stage (grades 9-10) and be enrolled in a general, madrasah or vocational stream school (see Table 2.1). In the general stream, the students select to follow a curriculum in either the humanities, science or business disciplines. In the madrasah stream, the students select between general, science, mujaddid and hifjulquaran (both 'mujaddid' and 'hifjulquaran' emphasise Islamic curriculum). In secondary vocational education, there is no subdivision and two years of the certificate program is offered. At the end of the senior secondary stage (or grade 10) learning achievement is assessed at the public examination, known as the Secondary School Certificate (SSC), in the general stream, the Dakhil in the madrasah stream, and the SSC Vocational in the vocational stream. The institutes (or schools) in the secondary education consist of public and private institutes. The public (government) institutes are managed and fully funded by the Bangladesh government. The private (non-government) institutes are managed independently, however, may either be funded by government subsidy or independently sources. The Ministry of Education (MoE) is responsible for the secondary education as well as the tertiary education. 


\section{BACHELOR OF EDUCATION PROGRAM IN BANGLADESH}

Teacher education programs include coursework which focuses on equipping teachers with knowledge and understanding of student needs, development and learning, pedagogical knowledge and, content area knowledge (Stronge, 2007). The aim of the secondary teacher education in Bangladesh (i.e. Bachelor of Education program) is to re-orientate secondary teachers' understanding of what constitutes teaching and produces a change in their classroom practice that increases student achievement (B.Ed. Curriculum, 2006-2007). Its purpose is to build teacher capacity in the form of new knowledge, skills and attitudes and in the application of these in practice. The curriculum of teacher education is, therefore, based on a defined set of teacher competencies and its content selected to provide the programs that enable untrained teachers and teacher trainees to develop and demonstrate a range of competencies required to promote student learning (B.Ed. Curriculum, 20062007). Bachelor of Education (B. Ed.) program is titled as Bachelor of Education (Secondary Teaching) and the name of the award is Bachelor of Education. This course is for one academic session (one year long) and there are 1200 student learning hours. The accrediting institute of this program is National University and the implementing institutes are TTCs administered by the government and the private sector (B.Ed. Curriculum, 2006-2007, pp- $1 \& 8$ ). Teacher training for secondary teachers including the B.Ed. are currently being provided in a range of institutions as depicted in Table 1.

Table 1: Types of secondary teacher training institutes

\begin{tabular}{lc}
\hline Type of Institute & Number of Institut \\
\hline Government Teacher Training College (TTC) & 14 \\
Private Teacher Training College & 104 \\
Higher Secondary Teacher Training Institutions (HSTTI) & 05 \\
Bangladesh Madrasah Teacher Training Institute (BMTTI) & 01 \\
National Academy of Educational Management (NAEM) & 01 \\
Bangladesh Open University (BOU) & 01 \\
Institutes of Education and Research (IER), Dhaka University & 01 \\
\hline
\end{tabular}

Source: BANBEIS, 2014

The present B.Ed. syllabus has been revised under National University Act. 1992 (Act 37 of 1992) and has been in effect in the government and private TTCs from the academic year 2006-2007. The curriculum is structured into five learning areas (including the teaching practice) which are mentioned in Table 2 with the score distribution and hours involved in each learning area (based on single period $=45$ minutes, double period $=1.5$ hours ).

Table 2: Total hours for each learning area and marks distribution in the B. Ed. Program

\begin{tabular}{lcc}
\hline Learning Areas & Hours & Scores \\
\hline Professional studies & 108 & 100 \\
Educational studies & 216 & 200 \\
Teaching Studies & 432 & 300 \\
Technology and Research Studies & 108 & 100 \\
Teaching Practice & 336 & 300 \\
\hline Total & 1200 & 1000 \\
\hline
\end{tabular}

Source: B.Ed. Curriculum, 2006-2007 


\section{1 "Teaching Mathematics" course in B.Ed.}

"Teaching Mathematics" is a course of the B.Ed. training under 'Teaching Studies' learning area (see Table 2). This course provides a range of learning opportunities designed specifically for trainees seeking to become secondary mathematics teachers. The purpose of this course is to support trainees to develop the knowledge, skills and attitudes required to competently teach mathematics in the Bangladesh secondary school curriculum for years 6-8 and years 9-10.

Table 3: Units and Contents of "Teaching Mathematics" course in B. Ed

\begin{tabular}{|l|l|}
\hline \multicolumn{1}{|c|}{ Unit } & \multicolumn{1}{c|}{ Content } \\
\hline $\begin{array}{l}\text { Unit: Secondary } \\
\text { mathematics curriculum in } \\
\text { Bangladesh }\end{array}$ & $\begin{array}{l}\text {-mathematics and mathematics education, role and } \\
\text { values embedded in mathematics education, content } \\
\text { analysis mathematics curriculum documents 6-10, } \\
\text { identifying developmental and logical sequencing of } \\
\text { content, classifying content in terms of intellectual } \\
\text { challenge, social context \& maturity level of students. }\end{array}$ \\
\hline $\begin{array}{l}\text { Unit 2: Teaching learning } \\
\text { approaches in the } \\
\text { mathematics classroom }\end{array}$ & $\begin{array}{l}\text {-a good mathematics teacher, teacher competencies in } \\
\text { the context of mathematics, considerations in } \\
\text { implementing a lesson in a classroom }\end{array}$ \\
\hline $\begin{array}{l}\text { Unit 3: Logical approaches to } \\
\text { familiar topics }\end{array}$ & $\begin{array}{l}\text {-constructivism, logical approaches for using formula } \\
\text { and algebra, set and real numbers, linear equations, } \\
\text { inequalities \& graphs, relations, functions and graphs, } \\
\text { Pythagoras, congruent and similar triangles, circles, } \\
\text { logical proofs of mathematical theorems direct \& by } \\
\text { induction }\end{array}$ \\
\hline $\begin{array}{l}\text { Unit 4: Approaching difficult } \\
\text { topics }\end{array}$ & $\begin{array}{l}\text {-mathematical induction, problems related to-partial } \\
\text { fractions, circles, vectors, trigonometry, and locus in } \\
\text { geometry. }\end{array}$ \\
\hline $\begin{array}{l}\text { Unit 5: Planning lessons for } \\
\text { effective teaching } \\
\text { learning in mathematics }\end{array}$ & $\begin{array}{l}\text {-revisiting the content analysis completed in Unit 1, } \\
\text { planning a sequence of lessons planning individual } \\
\text { lessons, reflective practice, school visit-making } \\
\text { adjustments to plans to meet the needs of a class }\end{array}$ \\
\hline $\begin{array}{l}\text { Unit assessment of } \\
\text { student } \\
\text { achievement } \\
\text { Unit 7: Independent learning } \\
\text { in mathematics }\end{array}$ & $\begin{array}{l}\text {-formative assessment, summative assessment } \\
\text { and }\end{array}$ \\
\hline
\end{tabular}

Source: B.Ed. Curriculum, 2006-2007

The major goal of this course is to help B.Ed. trainees develop competence in secondary teaching in ways that enable them to become knowledgeable, skilled and confident in their role as mathematics teachers, interested and skilled in working cooperatively with colleagues to plan and resource lessons and to sustain ongoing professional development. The content of the "Teaching Mathematics" course is divided into 06 (six) units and is briefed into Table 3.

\section{LITERATURE REVIEW}

\subsection{Teacher knowledge}

From the beginning of research into teacher knowledge, there have been differences in opinion about the kinds of teacher knowledge. Researchers investigating teachers knowledge have also aimed to 
develop a knowledge base for teaching and, where possible, translating it into a recommendation for teacher education (Reynolds, 1989). Stimulated by Shulman's work and his categories of knowledge bases (Shulman, 1986, 1987), researchers (Killen, 2013; Turner-Bisset, 2001) tended to develop model of knowledge base to sketch the requirement of the all the knowledge bases in effective teaching including defining the knowledge bases. For example, Killen (2013) categorized all the knowledge bases into four broad types: content knowledge, learner and learning knowledge, pedagogical knowledge, and pedagogical content knowledge. According to Killen (2013), Content knowledge is the knowledge of the subject or the discipline. This knowledge comprises of understanding the subject deeply (the concepts, principles and relationships that define the subject) and flexibly to help students create cognitive maps, link ideas, address misconceptions. Pedagogical knowledge is referred as how to guide students' learning in appropriate ways in specific circumstances, for example, how to attract and hold attention, and how to manage resources. Learner and learning knowledge includes how students learn that consists of different elements: empirical knowledge of learners and cognitive knowledge of learners to interpret learners' statements and actions and to shape productive learning experiences. Empirical knowledge is the knowledge in children physical, social and emotional domains. Cognitive knowledge of learner has two elementsknowledge of child development which inform practice and the other one is context-bound to a particular group of learners. Pedagogical content knowledge (PCK) is conceptualised as an overarching knowledge base comprising all of the knowledge- content knowledge, knowledge of learner and learning, and pedagogical knowledge and derived from the interaction and intersection of all these knowledge (Killen, 2013).

\subsection{Research on teacher training and content knowledge}

Researchers had explored the effect of teacher education or teacher training effectiveness using different approaches. Some researchers (for example, Farooq \& Shahzadi, 2006; Palardy \& Rumberger, 2008) had attempted the effect of teacher training program by investigating direct relationships between student achievement and teachers' participation in teacher training and teacher education programs. Farooq \& Shahzadi (2006) study in Pakistan evaluated effectiveness of teaching of trained and untrained teachers by comparing the mathematics achievement of 400 students by the teachers. Using descriptive survey design the study found significant differences in the teaching of trained and untrained teachers of mathematics and stressed that the teaching of trained teachers had a significant impact on the mathematics achievement of the students. Guarino, Hamilton, Lockwood \& Rathbun (2006) conducted a study using data from the Early Childhood Longitudinal Study, Kindergarten Class of 1998 -99 (ECLS-K) collected by National Centre for Education Statistics (NCES) in the USA. The study examined the relationship of teachers' background variables (teaching certification, coursework in pedagogy, employment status and, teaching experience) and instructional practices and student achievement (in reading and mathematics) during the kindergarten year. Using two-level hierarchical linear modelling (HLM), the study showed that only teachers' amount of coursework in pedagogy had a positive relationship with instructional practices (in reading and mathematics) that were associated with higher students' achievement in both subjects. Also, the study found instructional practices were positively associated with student achievement gains in both subjects but, no direct relationship between the qualifications of teachers and student achievement with the exception of teachers' employment status (part-time and fulltime).

Investigating the relationship between teachers mathematical content knowledge, instructional quality, and students' mathematical score, several studies (Baumert et al., 2010; Harbison \& Hanushek, 1992; Mullens, Murnane \& Willett, 1996; Rowan et al., 1997) administered mathematical test/quiz to the teachers. For example, Baumert and colleagues (2010) in Germany investigated the extent to which content knowledge (CK) and pedagogical content knowledge (PCK) influenced instructional quality that, in turn, influenced students' learning gains in mathematics. The study was conducted in Germany for one year with a representative sample of Grade 10 students and their mathematics teachers. Students' pre-test and post-test was used to assess mathematics learning progress, a 13 items paper-and-pencil test to measure teachers content knowledge in mathematics, 
three knowledge dimensions (mathematical tasks, student thinking and multiple representation) to assess PCK, and different data sources (student's rating, teachers' task to students, expert coding and tapping perceptions) to assess instructional quality into three dimensions (cognitive activation, individual learning support, and effective classroom management). By using the multilevel structural equation model the study revealed that both the CK and PCK had a correlation with their instructional approaches as well as students' learning outcomes. On the other, some researchers (Ball, 1990; Heaton, 2000; Ma, 1999; Simon, 1993) used interviewing teachers in investigating teachers' mathematical content knowledge to provide a more informative picture. However, though research (Ernest, 1989, Rowan et al., 1997; Swafford et al., 1997) consistently shows the importance of content knowledge in regard to instructional quality and developed observation checklist to measure the content knowledge of teacher during teaching (for example, EED, 2014), there seem to have paucity of research that evaluated the teachers level of content knowledge using observation checklist.

\section{CONCEPTUAL FRAMEWORK AND RESEARCH QUESTION}

The main findings of the literature review above provided the basis for the development of a conceptual framework for the study. The conceptual framework allowed a relative comparison of teachers' mathematical content knowledge covering the areas in algebra, trigonometry, and geometry to measure the secondary school mathematics teacher effects particularly the participation in the teacher education program (B.Ed.) on their secondary mathematics content knowledge. With respect to the purpose of the study, the single research question guided the study: Is there any difference between trained and untrained mathematics teachers in their teaching practices of mathematics? The question refers to the development of secondary mathematics content knowledge that the teachers had gained through the B.Ed. training program. Besides, this study also examined whether teachers' personal characteristics such as age, duration of service, academic qualification, type of the institute and so forth had any relationship with their content knowledge.

\subsection{Data Collection}

\subsubsection{Assessment test}

Primary data was collected by administering a mathematical test on two groups of teachers as well observing their classroom teaching. The items/questions in the assessment test were adopted from the test used in the Bangladesh Rural Advancement Committee (BRAC) research on "Evaluation of PACE Training for Mathematics Teachers of the Rural Non-Government Secondary Schools" in 2007. The assessment test consisted of ten questions chosen from the contents of Units 3 (Logical approaches to familiar topics) and Unit 4 (Approaching difficult topics) that concretely dealt with the mathematical subject knowledge. The test the duration of which was one hour was administered at the teacher's school in the teachers' native language, Bangla. The total score for the test was 100 with 10 scores for each question. All answer sheets of the assessment tests were evaluated by one mathematics instructor of Dhaka TTC and rechecked by the researcher.

\subsubsection{Classroom observation}

The researcher along with the headmaster of participant teachers' school and/or with the B.Ed. trainer of Dhaka Teacher Training College observed the general mathematics classroom teaching either in grade IX or grade $X$ to assess the depth of content knowledge in mathematics teaching. The item 'Depth of content knowledge' had been adopted from the observation checklist which is used as the "Teaching Practice Assessment Form" to assess the teacher trainees' classroom teaching of the B.Ed. program. This checklist has a five point rating scale from 1 to 5 where 1 refers to poor, 2 refers to fair, 3 indicates good, 4 refers to better, and 5 for the best performance in the teaching behaviour. Scoring for the depth of teachers' content knowledge was done by observing the two aspects of teaching-Clear logical steps in lesson delivery and Competency of the solving problems. 


\subsection{Data analysis}

The collected data was analyzed quantitatively. For the quantitative analysis, the descriptive statistics were computed using the SPSS version 22.0. Pearson Product Moment Correlation (Pearson Correlation and Kruskal-Wallis H-test) was used to find out the significant correlation between teachers' personal characteristics (age, teaching experience, academic attainment and the type of institute they serve) and their content knowledge.

\subsection{Design and sample}

A non-experimental comparative approach was employed in the study in order to measure the effectiveness of the B.Ed. program on secondary school mathematics teaching by comparing the secondary mathematics content knowledge of B. Ed trained mathematics teachers' and untrained mathematics teachers. A sample of the study was drawn through convenient sampling strategy. 23 B.Ed. trained (60\%) secondary school mathematics teachers and 15 untrained (40\%) secondary school mathematics teachers were identified from 4 public and 12 private secondary schools of Dhaka city. Mathematics teachers who had already undergone the Bachelor of Education (B.Ed.) training were considered as trained teachers while those who had neither B. Ed. training nor received any kind of professional training in mathematics were considered as untrained teachers. Mathematics is taught as a compulsory subject from grade $I$ to grade $X$ in Bangladesh secondary schools. In order to maintain the reliability of the observation data, the mathematics teaching either in grade IX or $\mathrm{X}$ were observed.

\section{INTERPRETATION OF THE RESULTS}

\subsection{Particulars of the sample}

The demographic data of all the 38 teachers included their gender, age, academic background, type of institute, experiences in teaching. Table 4 describes there are 38 teachers in which $74 \%$ were male and $26 \%$ were female.

Table 4: Gender of the teachers

\begin{tabular}{lccc}
\hline Gender & Frequency & Percent & Cumulative Percent \\
\hline Male & 28 & 74 & 74 \\
Female & 10 & 26 & 100 \\
Total & 38 & 100 & \\
\hline
\end{tabular}

Table 5 describes that the majority of the teachers (58\%) are below 40 years while $32 \%$ teachers were $41-50$ years. A few teachers (10\%) are older than 50 years.

Table 5: Age of the teachers

\begin{tabular}{lccc}
\hline Age & Frequency & Percent & Cumulative Percent \\
\hline Below 30 & 9 & 24 & 24 \\
$31-40$ & 13 & 34 & 58 \\
$41-50$ & 12 & 32 & 90 \\
$51-60$ & 4 & 10 & 100 \\
Total & 38 & 100 & \\
\hline
\end{tabular}

In the sample of the study, it can be seen from Table 6 that majority of the teachers had the Master's degree in the academic qualification which can be assumed a plus point for secondary education sector of Bangladesh. The rest of the teachers either had honors or graduation degree. 
Sheikh Asadullah

Effects of Teacher Training on Secondary Teachers' Mathematical Content Knowledge in Dhaka, Bangladesh

Table 6: Academic qualification of the teachers

\begin{tabular}{lccc}
\hline Qualifications & Frequency & Percent & Cumulative Percent \\
\hline Hons./Pass & 14 & 37 & 37 \\
Masters & 24 & 63 & 100 \\
Total & 38 & 100 & \\
\hline
\end{tabular}

Table 7 depicts the mathematics teaching experiences of teachers. The majority of the teachers had 11-20 years of teaching experience in mathematics. 5 untrained teachers were novice who had less than 1-year experience. Most likely only 2 teachers ( 1 trained and 1 untrained) had more than 30 years of mathematics teaching experience (see Table 7).

Table 7: Mathematics teaching experience of the teachers

\begin{tabular}{lccc}
\hline Experience & Frequency & Percent & Cumulative Percent \\
\hline Below 1 year & 5 & 13 & 13 \\
10 & 10 & 26 & 39 \\
L-20 & 12 & 32 & 71 \\
L-30 & 9 & 24 & 95 \\
Above 30 & 2 & 5 & 100 \\
Total & 38 & 100 & \\
\hline
\end{tabular}

In the sample of the study, most of the teachers were related to private schools and only $20 \%$ were from the government schools (see Table 8 ). In Bangladesh about $98 \%$ secondary schools are private and $97 \%$ teachers are from public secondary schools (BANBEIS, 2014).

Table 8: Type of schools

\begin{tabular}{lccc}
\hline Institute & Frequency & Percent & Cumulative Percent \\
\hline Public & 8 & 20 & 20 \\
Private & 30 & 80 & 100 \\
Total & 38 & 100 & \\
\hline
\end{tabular}

According to the demographical characteristics of both the untrained and the trained teachers, a significant difference was observed only with relation to the age and teaching experience between the trained and the untrained groups. In regard to the teachers' age, computing the independent $t-$ test at $5 \%$ significance level, it was found that the received p-value was 0.037 (less than the predetermined alpha 0.05 ) where $t$ value was 2.163 . For the teaching experience, the $p$-value was found 0.045 and the $t$ value was 2.079 .

\subsection{Mathematical content knowledge of the teachers}

The mathematical content knowledge of teachers was analyzed in two aspects; assessment test and the depth of content knowledge through classroom teaching observation. In both aspects, significant differences were found between the two groups of teachers which showed trained teachers were better than the untrained teachers due to the impact of B.Ed. training. In addition, non-parametric test was conducted to support the findings of the assessment test and the classroom teaching observation.

\subsubsection{Assessment test}

As mentioned earlier, the assessment test consisted of ten questions was administered to all 38 teachers to measure their level of content knowledge in the three areas: Algebra ( 7 items: questions 
1-7), Trigonometry ( 1 item: question 8 ), and Geometry ( 2 items: questions 9 and 10 ). Further, the seven questions of the algebra covered real number, set, inequalities, equation, determinants, function, and geometrical sequences.

Appendix 1 depicts the scores of the two groups (trained and untrained teachers) in this assessment test including the mean score and is summarized in Table 9. It could be seen from Appendix 1 and Table 9 that the mean of the total score in the assessment test of the trained teachers was higher than that of the untrained teachers. The score of the content knowledge of the trained group ranged from 89-100 whereas the range score of the untrained teacher was 78-100. In the trained group, $100 \%$ of teachers scored more than 88 out of 100 marks whereas only $60 \%$ of untrained teachers scored more than 88 . To obtain the full marks (i.e. 100), $22 \%$ trained and $20 \%$ untrained teachers were successful (see Table 9).

Table 9: Comparison of the teachers' performance in the assessment test

\begin{tabular}{lccc}
\hline Teachers & Range & Scored Above 8 & Scored 100 (full mark \\
\hline Trained & $89-100$ & $100 \%$ & $22 \%$ \\
Untrained & $78-100$ & $60 \%$ & $20 \%$ \\
\hline
\end{tabular}

Based on the data on Appendix 1, the mean score for each item, in the three major areas (Algebra, Trigonometry and Geometry), and in the test are summarised in Table 10. It can be seen from Table 10 that the mean scores of each item as well for three areas for the trained group are greater than those of untrained group of teachers. Table 10 also shows that overall score for the trained teachers $(96.30 \%)$ in the test was greater than that of the untrained teachers $(91.67 \%)$.

Table 10: Mean scores (in percentage) of the teachers in the assessment test

\begin{tabular}{lccc}
\hline \multirow{2}{*}{ Area } & \multirow{2}{*}{ Item(s) } & \multicolumn{2}{c}{ Mean score (\%) } \\
\cline { 3 - 4 } & & Trained Teachers & Untrained Teachers \\
\hline Algebra & 1 & 100 & 95.3 \\
& 2 & 90 & 89.3 \\
& 3 & 88.7 & 84.7 \\
& 4 & 100 & 89.3 \\
& 5 & 96.5 & 94.7 \\
& 6 & 96.1 & 87.3 \\
& 7 & 96.5 & 92.0 \\
\hline Trigonometry & Mean score & 95.4 & 90.3 \\
\hline Geometry & 8 & 100 & 98.0 \\
& Mean score & 100 & 98.0 \\
& 9 & 100 & 98.0 \\
\hline Mean score in all areas & 10 & & 97.3 \\
\hline & & 98.7 & 88.7 \\
& & 96.5 & 93 \\
\hline
\end{tabular}

\subsubsection{Weak Areas in Mathematics (according to the test)}

Table 11 shows the percentage of teachers who scored full marks (100\%) for each item of the test. Hence, it can be claimed that the untrained teachers were weaker in content knowledge of mathematics than the trained teachers in exception of the geometrical sequence as in geometry both groups had a similar score. Further, it can be seen that though all the trained teachers had shown 
their full level of competency in three subareas: real number, equation and trigonometry, all the untrained teachers were not able to show their competency in any subarea of the test. However, inequalities had been revealed as the weakest area for both groups (see Table 11).

Table 11: Teacher(s) scored full marks (100\%) in each Item

\begin{tabular}{l|cc}
\hline Item no. \& content of the question & $\begin{array}{c}\text { Trained Teacher! } \\
\mathbf{( \% )}\end{array}$ & $\begin{array}{c}\text { Untrained Teacher! } \\
\mathbf{( \% )}\end{array}$ \\
\hline Q1- Real number & 100 & 73 \\
Q2- Set & 70 & 60 \\
Q3- Inequalities & 48 & 47 \\
Q4- Equation & 100 & 73 \\
Q5- Determinants & 87 & 80 \\
Q6- Function & 78 & 67 \\
Q7-Geometrical sequences & 87 & 87 \\
Q8- Trigonometry & 100 & 87 \\
Q9 \& 10- Geometry & 87 & 73 \\
\hline
\end{tabular}

\subsubsection{Depth of content knowledge exhibited in classroom teaching}

23 teachers' (15 trained and 8 untrained) depth of teachers content knowledge had been measured on a 5 point Likert scale by observing the performance of trained and untrained teachers in two aspects - Clear logical steps in lesson delivery and Competency of the solving problems in their classroom teaching. Table 12 presents the score in the depth of content knowledge of the teachers exhibited in their classroom teaching.

Table 12: Comparison between the trained and untrained teachers in depth of content knowledge (demonstrated in classroom teaching)

\begin{tabular}{llcccccc}
\hline \multirow{2}{*}{ Content } & Teachers & \multicolumn{7}{c}{ Score } \\
\cline { 3 - 8 } & & $\mathbf{5}$ & $\mathbf{4}$ & $\mathbf{3}$ & $\mathbf{2}$ & $\mathbf{1}$ & Mean \\
\hline Depth of teachers & Trained & $42 \%$ & $50 \%$ & -- & -- & $8 \%$ & 4.17 \\
content knowledge & Untrained & $9 \%$ & $27 \%$ & $37 \%$ & $18 \%$ & $9 \%$ & 3.09 \\
\hline
\end{tabular}

From Table 12 it can be seen that most of the trained teachers (50\%) scored 4 on the 5 point Likert while most of the untrained teachers (37\%) scored 3. To compare the full score (score 5) obtained by the teachers, $42 \%$ trained teachers and $9 \%$ untrained teachers had the full score. Thus, the overall score of the content knowledge demonstrated through teaching of the trained teachers was $4.17(83.40 \%)$, on the contrary, the score for the untrained teachers was $3.09(61.90 \%)$.

The Mann-Whitney $U$ test, $(Z=2.442$ and $p=0.015)$ showed that there was a difference in the score of the content knowledge between the two groups; similarly, it indicated that the teaching mathematics between the two groups of teachers was significant. It was further confirmed by the results of the t-test at the $5 \%$ significance level $(p=0.032 ; t=2.291)$. Therefore, the trained teachers were more competent in solving problems in their classroom teaching and followed clearer logical steps in lesson delivery than the untrained group of teachers.

In addition to the above analysis, the depth of content knowledge performance of trained and untrained teachers had been analysed in above two aspects through the qualitative indicators of the classroom teaching (Appendix 2) and the frequency of the score distribution (See Table 13). The qualitative indicators of the classroom teaching were developed by the researcher in consultation with the B. Ed trainer. The subsequent sections (see section 7.2.2.1 and 7.2.2.2) present the mixed 
analysis of the performance of trained and untrained teachers in above two aspects that reveal the significant difference between the depth of teachers content knowledge of the two group of teachers.

\subsubsection{Clear logical steps in lesson delivery}

From Table 13 it can be seen that, in maintaining clear logical steps in the lesson delivery, trained teachers $(M=3.00)$ showed better performance than their counterparts $(M=2.91)$. According to the criteria of the Likert scale (see section 6.2),67\% trained and $63 \%$ untrained teachers made clear logical steps in the lesson delivery. Of the trained teachers, $42 \%$ made the topic clearer and followed the steps according to the difficulty level. While demonstrating the lesson, the $42 \%$ teachers were conscious about mentioning in details all steps of the mathematical problem, maintained the difficulty level by linking up the formulas or calculation with the problem. In addition, they also stated some common errors students generally made in the exam and advised students to be careful about these errors. On the contrary, $36 \%$ untrained teachers showed such characteristics in demonstrating the lesson in order to make the topic clearer and in guiding the students about the common errors. However, $8 \%$ trained teachers and $9 \%$ untrained teachers failed to make the topic clear, did not maintain the steps according to the difficulty level, and skipped the clear steps of the solution process or did not well link up the formula with the problem.

\subsubsection{Competency in solving problems}

In observing the classroom teaching, trained teachers $(M=1.17)$ were found to be more competent in solving the problems than the untrained teachers $(M=0.18)$ (see Table 13). According to the Likert scale (see Section 6.2), 42\% trained teachers and $9 \%$ untrained teachers were found to express mathematics terms in "Linguistic Representation" as well as used students' familiar examples. The trained teachers solved the problems on the blackboard with more detailed oral explanations. In addition, the observers and the students (of the respective sessions) did not notice any mistake in trained teachers' explanations of solutions on the blackboard. On the contrary, some untrained teachers were found in making mistakes in their explanations of the solutions.

Table 13: Comparison between the trained and untrained teachers in maintaining logical steps in lesson delivery and competency in solving problems

\begin{tabular}{llcccccc}
\hline \multirow{2}{*}{ Content } & Teachers & \multicolumn{7}{c}{ Score } \\
\cline { 3 - 8 } & & $\mathbf{5}$ & $\mathbf{4}$ & $\mathbf{3}$ & $\mathbf{2}$ & $\mathbf{1}$ & Mean \\
\hline Clear logical steps in & Trained & $0 \%$ & $42 \%$ & $25 \%$ & $25 \%$ & $8 \%$ & 3 \\
lesson delivery & Untrained & $0 \%$ & $36 \%$ & $27.5 \%$ & $27.5 \%$ & $9 \%$ & 2.91 \\
\hline Competency in solving & Trained & $0 \%$ & $17 \%$ & $25 \%$ & $0 \%$ & $25 \%$ & 1.67 \\
problems & Untrained & $0 \%$ & $9 \%$ & $0 \%$ & $0 \%$ & $27 \%$ & 0.64 \\
\hline
\end{tabular}

\subsubsection{Nonparametric test}

\subsubsection{The assessment test}

To investigate any statistically significant differences among the scores of three areas: Algebra, Trigonometry and Geometry of mathematics in the assessment test, Levene's test was computed. In Algebra, the p-value $(0.041)$ was less than the predetermined alpha $(0.05)$ while the $p$-value in Trigonometry $(p=0.093)$ and in Geometry $(p=0.086)$ was bigger than the predetermined alpha $(0.05)$. Thus, the results indicated that there was a statistically significant difference between the content knowledge in Algebra of the trained teachers and the untrained teachers where $t$ value was 2.12. Further, the t-test result of the overall score in the test between the two groups shows a statistically significant difference between these two groups regarding overall content knowledge of mathematics $(p=0.015, t=2.553)$. 


\subsubsection{The depth of content knowledge exhibited in classroom teaching}

The results from the Mann-Whitney $U$ test showed that there was a statistically significant difference between the two groups in the score of the content knowledge during teaching $(Z=2.442, p=$ 0.015 ). The finding was further confirmed by the results of the t-test at the $5 \%$ significance level ( $p$ $=0.032 ; \mathrm{t}=2.291$ ).

\subsubsection{Summary of the analysis}

Based on the above results and analysis of the assessment test, classroom observation and the nonparametric test, it can be claimed that mathematics trained teachers possessed more content knowledge than the untrained group did. The difference for the level of content knowledge was significant in algebra and in classroom teaching particularly in solving problems and in presenting clearer logical sequences in lesson delivery.

\subsection{Relationship between teachers' personal characteristics and content knowledge}

One of the purposes of this study was to find out any significant relationship between the two groups of teachers with regard to their personal characteristics (age, experience, qualification, and institution type) and their mathematical content knowledge.

\subsubsection{Correlation with teachers' age and experience}

The Pearson correlation (two tails) test at 5\% level of significance was used to measure the correlation of teachers' age, experience with their content knowledge. The summary results are shown in Table 14. As shown in Table 14, it can be revealed that there was no significant relationship between teachers' age and their experience with their content knowledge.

Table 14: Correlation of teachers' age and experience with content knowledge

\begin{tabular}{lll}
\hline Variables & Teachers Age & Teaching experience \\
\hline \multirow{2}{*}{ Content Knowledge } & $\mathrm{Irl}=0.294$ & $\mathrm{Irl}=0.246$ \\
& $p=0.073>0.05$ & $p=0.137>0.05$ \\
\hline
\end{tabular}

\subsubsection{Correlation with qualification and type of the institute}

The Kruskal-Wallis $\mathrm{H}$-test at $5 \%$ level of significance was used to observe the relationship. The summary results are shown in Table 15. According to the results in depicted in Table 7, it was found that there was no significant relationship between teachers' qualification and the type of the institutes they served with their content knowledge in mathematics.

Table 15: Correlation of teachers' qualification and the type of institute with content knowledge

\begin{tabular}{lll}
\hline Variables & Qualification & Type of Institute \\
\hline \multirow{2}{*}{ Content knowledge } & $\mathrm{H}=0.045$ & $\mathrm{H}=3.718$ \\
& $\mathrm{p}=0.831>.05$ & $\mathrm{p}=0.054>.05$ \\
\hline
\end{tabular}

\section{DISCUSSION OF THE FINDINGS}

Research question 1: Is there any difference between the trained and the untrained mathematics teachers in their content knowledge?

The study found that the trained teachers were ahead of the untrained teachers in the content knowledge level of mathematics. In the assessment test as well as in the depth of content knowledge while teaching, the trained teachers performed better than their counterparts. The nonparametric tests confirmed the findings combined with a significance difference in the level of content knowledge 


\section{Sheikh Asadullah \\ Effects of Teacher Training on Secondary Teachers' Mathematical Content Knowledge in Dhaka, Bangladesh}

(both in assessment test and depth of content knowledge in classroom teaching) between the trained and the untrained group.

In the assessment test, the variance of the trained teachers' mathematical knowledge was lower $(100-89=11)$ than that of the untrained teachers $(100-78=22)$. All trained teachers were able to score $89 \%$ marks in the test whereas the untrained teachers' minimum score was $78 \%$. This suggests that through the training, the trained teachers could confirm the certain level of competency $(89 \%)$ in mathematics.

In the assessment test, the variance of the trained teachers' mathematical knowledge was lower $(100-89=11)$ than that of the untrained teachers $(100-78=22)$. All trained teachers were able to score $89 \%$ marks in the test whereas the untrained teachers' minimum score was $78 \%$. This suggests that through the training, the trained teachers could confirm the certain level of competency $(89 \%)$ in mathematics.

As observed, the trained teachers showed the depth of content knowledge than the untrained teachers while teaching mathematics in the classroom. Possessing better content knowledge by the trained teachers revealed in the assessment test could have facilitated them to conduct their sessions by delivering the lessons more logically and precisely to the students and to perform better in solving problems in the classroom.

\section{Research question 2: Is there any relationship between teacher's personal characteristics and content knowledge?}

In the two groups of teachers in this study, significant differences were found between age and teaching experiences. Nevertheless, the differences did not have any impact on the differences found in content knowledge between the two groups of teachers since it was found that their age and teaching experience did not have any significant relation. No relationship was also found between teachers' academic qualification and the type of institutes they served. The older age, longer teaching experience and higher academic qualification did not guarantee better content knowledge. Whether the teachers worked in either a public or a private institute, it did not have any impact on those professional aspects.

Observing the personal characteristics of the teachers participated in this study, it was seen that, 17 $(73 \%)$ teachers from the age range between 25 and 40 and 7 teachers (44\%) from the age range of 41 and 57 possessed master level qualifications (see Table 1). Therefore, it is noteworthy to mention that more teachers with higher academic qualifications enter the secondary schools as teachers currently than earlier days; the reason may be due to the rising unemployment in Bangladesh. It was showed in Table 1 that, $26 \%$ untrained teachers were over 41 years of age and $74 \%$ were below 40 . The reasons may be due to the effective implementation of educational reforms by the Bangladesh government regarding the increase of the trained teachers' percentage in secondary schools. This was clear from the percentages of trained teachers in the years 2003, 2004, 2005 which were $48.6 \%, 50.5 \%, 53.6 \%$ respectively (BANBEIS, 2006).

\section{RECOMMENDATIONS}

The researcher has the following recommendations that have come out from the findings of the study:

- there should be continued and pre-scheduled training program for the secondary school teachers;

- to assess the development of the acquired knowledge and skills from the training, a "monitoring cell" should be introduced and maintained regularly by the authority;

- since teachers could not improve some areas of the mathematical content knowledge (i.e. inequalities, set, function, determinants, geometrical sequences, and geometry), more 
emphasis should be given on the areas in the "Teaching Mathematics" course/curriculum in the B.Ed. program.

\section{ACKNOWLEDGEMENTS}

A special appreciation and gratitude go to Associate Professor Hotta Taiji, Hiroshima University, Japan. His patience, appraisal, guidance and constructive criticism during the collection of data were of inestimable value. The author also owes many debts to the people who encouraged, supported and guided throughout the study, in particular, appreciates the support, and valuable suggestions offered by the members of the supervisory committee, Professor Norihiro Kuroda and Associate Professor Takuya Baba of Hiroshima University, Japan. The author extends his sincere gratitude to the Japan International Cooperation Agency (JICA) for scholarship support for his master's study at Hiroshima University, Japan that enabled him to carry out this study. Appreciation is extended to the government of Bangladesh for allowing him to study in Japan for two years. Finally, the author is also grateful to all the teachers, head teachers, instructors of Teachers Training College (Dhaka) for their kind support and assistance.

\section{REFERENCES}

- Ahmed, M., Nath, R., Hossain, A., \& Kalam, A. (2006). Education Watch 2005, The state of secondary education: Progress and challenge. Dhaka, Bangladesh: Campaign for Popular Education (CAMPE).

- Andaleeb, S. (Ed.). (2007). Political culture in Bangladesh: Perspectives and analysis. Dhaka, Bangladesh: Bangladesh Development Initiative.

- Asian Development Bank (ADB). (2002). Technical assistance to the People's Republic of Bangladesh for preparing the teaching quality improvement in secondary education project. Retrieved from http://www.adb.org/sites/default/files/project-document/71019/r17802.pdf

- Asian Development Bank (ADB). (2004). Report And Recommendation of The President to The Board of Directors on A Proposed Loan to the People's Republic Of Bangladesh For The Teaching Quality Improvement In Secondary Education Project. Retrieved from http://www.adb.org/sites/default/files/project-document/71019/r178-02.pdf.

- Bachelor of Education Curriculum, Effective form the Session: 2006-2007. National University, Gazipur. Ministry of Education, Government of the People's Republic of Bangladesh.

- Ball, D. (1990). "The Mathematical understandings that prospective teachers bring to teacher education", The Elementary School Journal, 90, pp. 449-466, CrossRef

- Ball, D., Lubienski, S., \& Mewborn, D. (2001). "Research on teaching mathematics: the unsolved problem of teachers' mathematical knowledge", In V. Richardson (Ed.), Handbook of Research on Teaching, Washington, DC: American Educational Research Association, pp. 433-456.

- Bangladesh Bureau of Educational Information and Statistics (BANBEIS) (2006). Bangladesh Educational Statistics 2006. Retrieved from official website www.banbeis.gov.bd

- Berliner, C. (1994). "Expertise: the wonder of exemplary performances", In N. Mangieri \& C. Block (Eds.), Creating Powerful Thinking in Teachers and Students, Fort Worth, TX: Holt, Rinehart \& Winston., pp. 161-186.

- Bransford, J., Darling-Hammond, L., \& LePage, P. (2005). "Introduction", In L. DarlingHammond \& J. Bransford (Eds.), Preparing Teachers for A Changing World, San Francisco: Jossey-Bass, pp. 1-39.

- Education and Early Development (EED). (2014). Teacher Classroom Observation Tool (Alaska Standards). Retrieved from http://education.alaska.gov/TeacherCertification/edeval.html. 
- Ernest, P. (1989). "The knowledge, beliefs and attitudes of the mathematics teacher: A model", Journal of Education for Teaching, 15, pp. 13 - 33, CrossRef

- Farooq, M. \& Shahzadi, N. (2006). "Effect of teachers' professional education on students' achievement in mathematics", Bulletin of Education \& Research, University of the Punjab, Lahore, Pakistan, 28.

- Fennema, E., \& Franke, M. L. (1992). "Teachers' Knowledge and its impact", in A. Grouws (Ed.), Handbook of Research on Mathematics Teaching and Learning, New York: Macmillan, pp. 147-164.

- Grossman, P. (2008). "Responding to our critics: from crisis to opportunity in research on teacher education", Journal of Teacher Education, 59, pp. 10-23, CrossRef

- Grossman, P. L., \& McDonald, M. (2008). "Back to the future: directions for research in teaching and teacher education", American Educational Research Journal, 45, pp. 184-205, CrossRef

- Guarino, C., Hamilton, L., Lockwood, J., \& Rathbun, A. (2006). Teacher Qualifications, Instructional Practices, and Reading and Mathematics Gains of Kindergartners (NCES 2006031). Washington, DC: U.S. Department of Education, National Center for Education Statistics.

- Harbison, R., \& Hanushek, E. 1992. Educational Performance of the Poor: Lessons from Rural Northeast Brazil. Oxford, UK: Oxford University Press.

- Hattie, J. (2003).Teachers make a difference: what is the research evidence? Paper presented at the Australian Council for Educational Research Annual Conference on Building Teacher Quality, Melbourne.

- Hattie, J. (2009). Visible Learning. A Synthesis of Over 800 Meta-Analyses Relating To Achievement. Routledge Taylor \& Francis Group.

- Heaton, R. (2000). Teaching Mathematics to the New Standards: Relearning the Dance. New York: Teachers College Press.

- Hiebert, J., Morris, A., Berk, D., \& Jansen, A. (2007). "Preparing teachers to learn from teaching", Journal of Teacher Education, 58, pp. 47-61, CrossRef

- Killen, R. (2013). Effective Teaching Strategies: Lessons From Research and Practice (6th Edn). South Melbourne, VIC: Cengage Learning Australia.

- Ma, L. (1999). Knowing and Teaching Elementary Mathematics: Teachers' Understanding of Fundamental Mathematics In China And The United States. Hillsdale, NJ: Erlbaum.

- Ministry of Education (MoE) (2013). Development of Education, National Report of Bangladesh. Retrieved from http://www.ibe.unesco.org/International/ICE47/English/Natreps/reports/bangladesh. pdf.

- Ministry of Education (MoE) (2012). Official website of Ministry of Education, Bangladesh. www.moe.gov.bd.

- Mullens, J., Murnane, R., \& Willett, J. (1996). "The contribution of training and subject matter knowledge to teaching effectiveness: a multilevel analysis of longitudinal evidence from Belize", Comparative Education Review, 40, pp. 139-157, CrossRef

- Munby, H., Russell, T., \& Martin, A. (2001). "Teachers' knowledge and how it develops", In V. Richardson (Ed.), Handbook of Research on Teaching. Washington, DC: American Educational Research Association, pp. 877-904.

- Nath, S., Haq, N., Begum,S., Ullah, A., Sattar, A., \& Chowdhury, A. (2007). Education Watch 2007: The State of Secondary Education Quality And Equity Challenges. Dhaka, Bangladesh: Campaign for Popular Education (CAMPE).

- Palardy, G., \& Rumberger, R. (2008). "Teacher effectiveness in first grade: the importance of background qualifications, attitudes, and instructional practices for student learning", Educational Evaluation and Policy Analysis, 30, pp. 111-140, CrossRef

- Rahman, M., Hamzah, M., Meerah, T. \& Rahman, M. (2010). "Historical development of secondary education in Bangladesh: colonial period to 21st century", International Education Studies, 3, pp. 114-125, CrossRef 


\section{Sheikh Asadullah}

Effects of Teacher Training on Secondary Teachers' Mathematical Content Knowledge in Dhaka, Bangladesh

- Reynolds, M. (Ed.). (1989). Knowledge Base for the Beginning Teacher. New York: Pergamon Press.

- Rowan, B., Chiang, F. S., \& Miller, R. J. (1997). Using research on employees' performance to study the effects of teachers on students' achievement. Sociology of Education, pp. 256284, CrossRef

- Shulman, L. (1986). "Those who understand: knowledge growth in teaching", Educational Researcher, 15, pp. 4-14, CrossRef

- Shulman, L. (1987). "Knowledge and teaching: foundations of the new reform", Harvard Educational Review, 57, pp. 1-22, CrossRef

- Simon, M. (1993). "Prospective elementary teachers' knowledge of division", Journal of Research In Mathematics Education, 24, pp. 233-254, CrossRef

- Stronge, J. (2007). Qualities of Effective Teacher. Alexandria, VA: Association for Supervision and Curriculum Development.

- Swafford, J., Jones, G., \& Thornton, C. (1997). "Increased knowledge in geometry and instructional practice", Journal for Research in Mathematics Education, 28, pp. 476-483, CrossRef

- Turner-Bisset, R. (2001). The knowledge bases of the expert teacher", British Educational Research Journal, 25, pp. 39-55, CrossRef 